\title{
Preservare la memoria: dal rilievo digitale alla realtà virtuale per la conservazione del patrimonio naturale a rischio
}

\author{
Damiano Antonino Angelo Aiello \\ Cettina Santagati
}

Abstract

II contributo esplora e indaga il tema della fruizione virtuale nell'ambito della salvaguardia del patrimonio naturale a rischio. La sperimentazione è stata condotta sulla Grotta dei Pipistrelli sita nella Riserva Naturale di Pantalica (SR) e soggetta a pressione antropica che rischia di compromettere la preziosa biodiversità del sito. II progetto ha avuto lo scopo di raccogliere in modo sistematico le informazioni sulla grotta, dalla descrizione della morfologia alle caratteristiche geologiche-materiche e sulle specie che la abitano, con l'obiettivo di facilitare gli studi futuri e di creare una banca dati in grado di conservare la memoria di questo sito e di comunicarlo attraverso dei media innovativi.

La documentazione della geometria della grotta è stata raggiunta attraverso l'utilizzo combinato di tecniche di scansione laser e fotogrammetriche. II modello numerico così ottenuto ha costituito la base per lo sviluppo di un prototipo per la fruizione della grotta in Realtà Virtuale con l'obiettivo di permettere a tutte le categorie di utenti di esperire virtualmente questo luogo unico, di difficile accesso e ad elevato rischio, limitando così la pressione antropica sul sito reale.

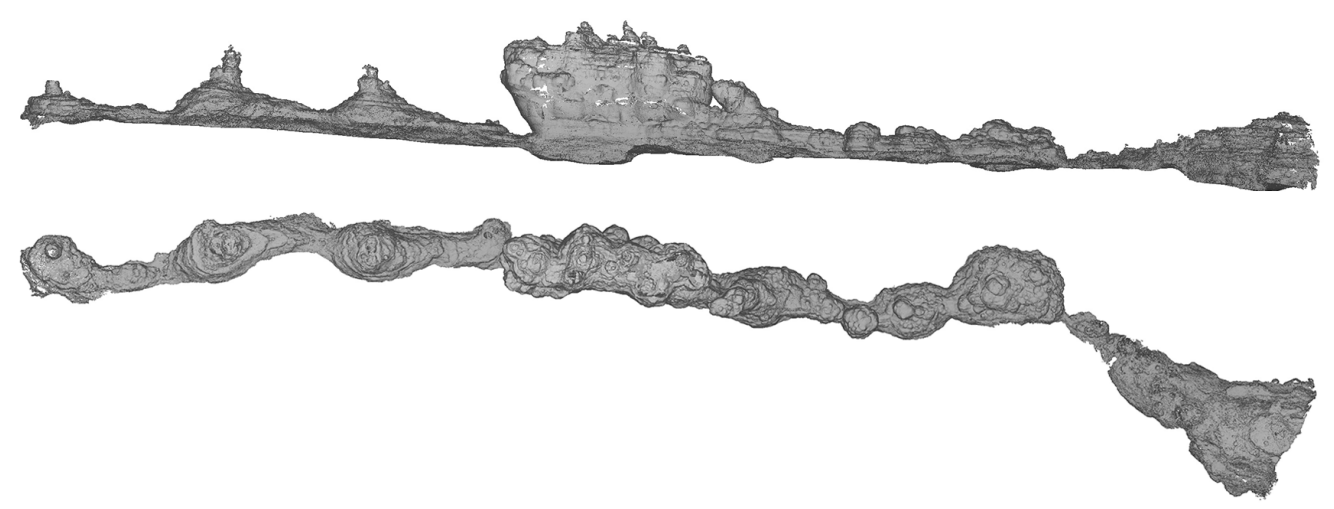




\section{Introduzione}

La memoria tramandata dal patrimonio culturale, inteso in senso lato (non solo le architetture, dunque, ma anche i beni di pregio naturale e paesaggistico), si caratterizza per il suo essere fragile, costantemente in bilico fra ricordo e oblio. In questo senso, essa non è un semplice documento, un arido archivio di informazioni e nozioni univoche, ma contiene sempre per sua natura delle zone d'ombra e dei tratti difficili da comprendere ed è spesso sfuggente, ambigua ed estremamente volatile, cioè costantemente soggetta al rischio di estinguersi. Per questa ragione, la memoria insita nel patrimonio rappresenta una sfida e uno stimolo per l'uomo, che ha non solo il dovere, ma anche il bisogno di indagarla, interpretarla e di trovare modi nuovi e sempre più efficaci per comprenderla e farla comprendere agli altri, proteggendola al contempo dalla sua stessa fragilità.

Su questi principi si basa la sperimentazione descritta in queste pagine, finalizzata ad indagare ed esplorare le potenzialità del tema della fruizione virtuale con riferimento alla documentazione e riproduzione digitale della Grotta dei Pipistrelli, situata nella Riserva Naturale di Pantalica (SR), iscritta nella WHL UNESCO dal 2005. La grotta costituisce un fragile ecosistema continuamente soggetto a pressione antropica che rischia di compromettere la preziosa biodiversità del sito (ad oggi uno dei siti più importanti del Mediterraneo che ospita colonie riproduttive di chirotteri).

II progetto ha avuto lo scopo di raccogliere in modo sistematico le informazioni sulla grotta, dalla descrizione della morfologia alle caratteristiche geologiche-materiche e sulle specie che la abitano, con l'obiettivo di facilitare gli studi futuri e di creare una banca dati in grado di conservare la memoria di questo sito e di comunicarlo attraverso dei medium innovativi. Al fine di raggiungere questo obiettivo, il team di ricerca ha effettuato il rilievo della grotta attraverso l'utilizzo combinato di tecniche di scansione laser e fotogrammetriche, che hanno permesso di ottenere un modello numerico, duplicato digitale dell'ambiente studiato, che potrebbe costituire la base per condurre studi interdisciplinari di diversa natura (ad esempio, il modello potrà essere collegato in futuro a sensori che permettono il monitoraggio in tempo reale delle condizioni ambientali).

Infine la ricerca si è focalizzata sullo sviluppo di un prototipo per la fruizione della grotta in Realtà Virtuale con l'obiettivo di permettere a tutte le categorie di utenti di esperire virtualmente questo luogo unico, di non facile accesso e ad elevato rischio, limitando così la pressione antropica sul sito reale.

Fig. I. Localizzazione della Grotta dei Pipistrelli nella Riserva Naturale orientata "Pantalica, valle dell'Anapo e torrente Cavagrande".

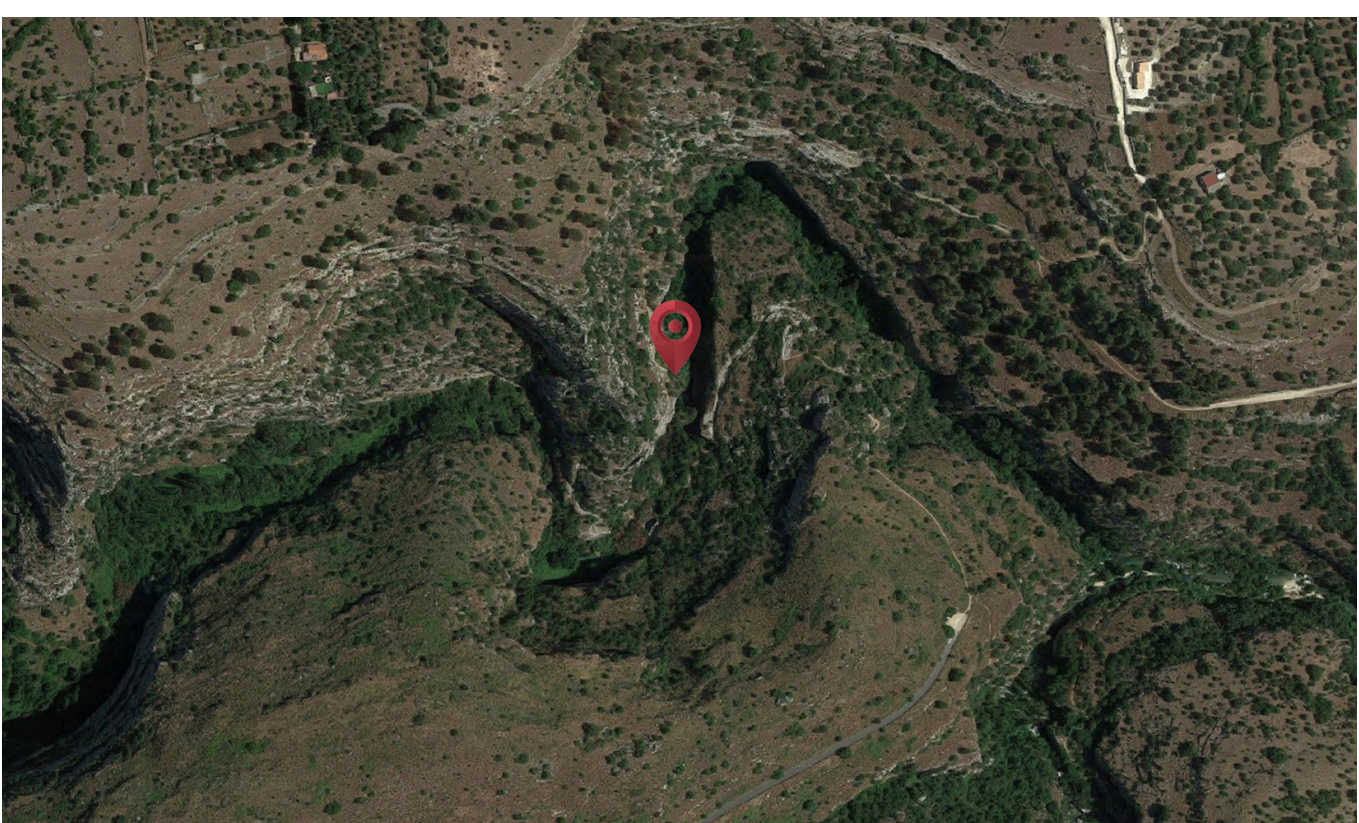




\section{Stato dell'arte}

Nel caso del patrimonio naturale, e più nello specifico degli ambienti ipogei, il rilievo si configura come una grande sfida, considerando le peculiarità di questi luoghi unici (le morfologie complesse, il livello di illuminazione ecc.). Fino ad ora, la maggior parte dei rilievi all'interno di grotte e cavità sotterranee è stata condotta attraverso tecniche tradizionali, mentre quelle più innovative (come il rilievo digitale) sono ancora poco sviluppate in questo ambito, considerando che richiedono competenze tecniche non sempre alla portata di tutti. Nonostante questo, il rilievo digitale (effettuato attraverso laser scanner e tecniche fotogrammetriche) è indubbiamente lo strumento più efficace in termini di velocità e precisione, essendo in grado di fornire in tempo relativamente breve informazioni estremamente dettagliate e con un'accuratezza nota [Buchroithner et al. 20 I I; Mohammed Oludare et al. 20 I6, p. 8; Fabbri et al. 20 I7, pp. I6-29].

Negli ultimi anni, numerose ricerche si sono focalizzate sulla combinazione di diverse tecniche di rilievo per ottenere risultati più soddisfacenti [Cabrelles López et al. 20 I3, pp. 64-68] oppure sull'uso di diversi strumenti come i sistemi multi-camera [Nocerino et al. 2018, pp. 329-337], gli obiettivi fisheye (Alessandri et al. 2019, pp.25-32) o le fotocamere dei telefoni cellulari per acquisire spazi molto stretti e complessi [Alessandri et al. 20 I9, pp. 37-4 I].

I dati acquisiti durante il rilievo digitale diventano un ottimo database attraverso il quale è possibile conservare la memoria di un luogo e studiarlo approfonditamente. Inoltre, possono essere utilizzati per creare esperienze di VR, con lo scopo di conoscere, documentare e rendere virtualmente accessibili luoghi estremi come gli ambienti ipogei [Nocerino et al. 20I9, pp. 857-864; Paganini et al. 20I I, pp. 2I-25].

In questo senso, la realtà virtuale aiuta a superare le barriere fisiche, dando la possibilità di visitare e interagire virtualmente con luoghi lontani, rendendo accessibili anche siti a rischio nei quali l'ingresso è vietato per ragioni di tutela e conservazione [De Vos et al. 2019, pp. 397-404; Trizio et al. 20 |9, pp. I | 7 | - I | 78].

L'efficacia di queste simulazioni virtuali può essere potenziata attraverso il paradigma del Serious Game, ovvero un gioco concepito per uno scopo educativo diverso dal puro divertimento. Questo tipo di esperienza può fornire all'utente la possibilità di acquisire conoscenze in prima persona, stimolando la sua memoria e la sua curiosità in modi innovativi ed emotivamente coinvolgenti [Aiello et al. 2019, pp. 33-40; Bolognesi et al. 20 I9, pp. 49-75].

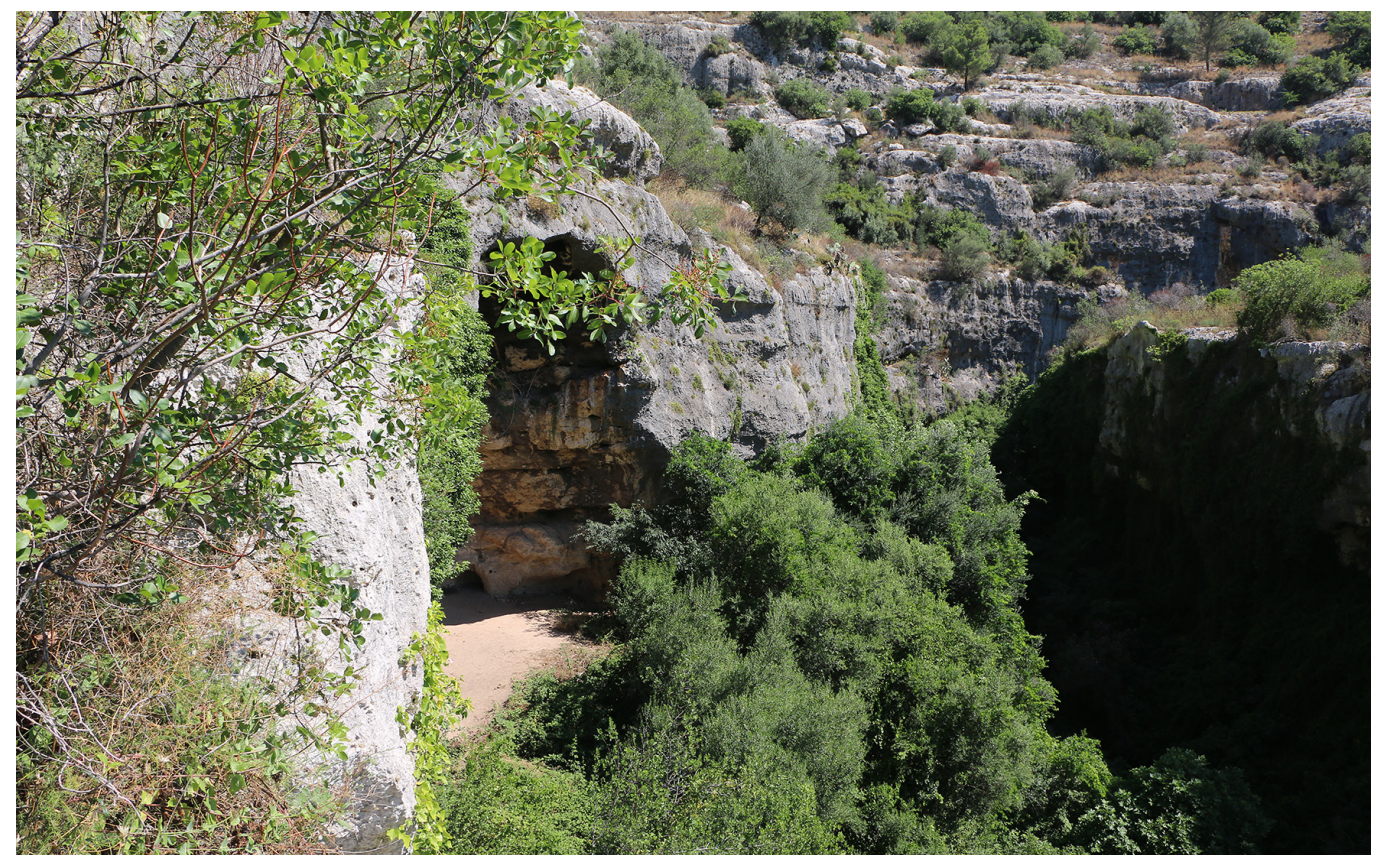




\section{La Grotta dei Pipistrelli a Pantalica}

La Grotta dei Pipistrelli, così chiamata per l'elevato numero di esemplari di pipistrelli che ospita, è un sito estremamente rilevante per la salvaguardia della chirotterofauna siciliana. La grotta, una delle più grandi cavità carsiche della Riserva naturale orientata "Pantalica, valle dell'Anapo e torrente Cavagrande", si apre su una parete rocciosa quasi a strapiombo sul torrente Calcinara (figg. I, 2).

Il profondo ambiente ipogeo, interessato da uno sviluppo pressoché orizzontale è percorribile per un tratto lungo circa 260 metri. La sala d'accesso alla grotta, denominata talus, è costituita da un antro largo $18 \mathrm{~m}$, lungo $28 \mathrm{~m}$ e alto circa $15 \mathrm{~m}$ che si restringe a imbuto trasformandosi in uno stretto condotto lungo $12 \mathrm{~m}$, al termine del quale si trova un cancello [I] da cui si accede ad una grande sala lunga circa $22 \mathrm{~m}$ e alta II m, cui fa seguito un condotto che presenta sulle pareti e sul soffitto morfologie freatiche, quali megascallops, cupole

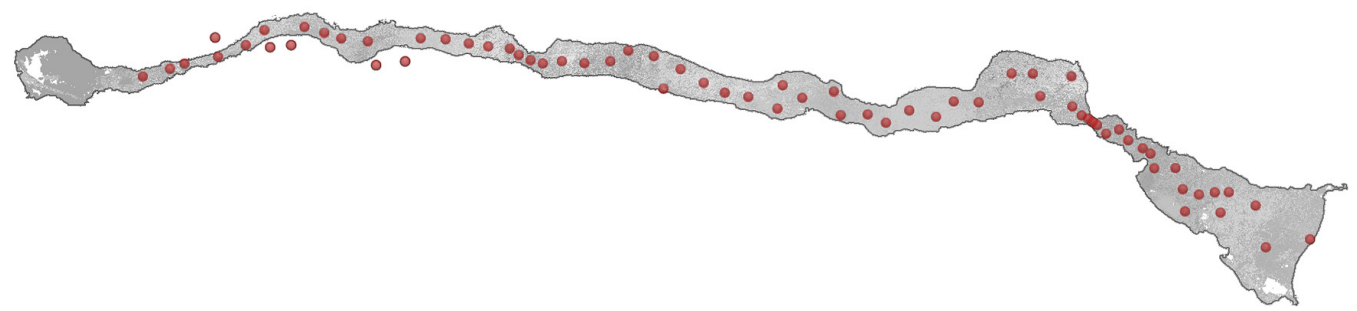

e solchi laterali. Segue l'ambiente più grande di tutta la grotta, denominato "Sala del Guano", caratterizzato da una volta costituita da tre cupole compenetrate e avente un'altezza massima di $30 \mathrm{~m}$ e una lunghezza di circa $40 \mathrm{~m}$. È proprio in questo ambiente che trovano asilo le diverse specie di pipistrelli che, per numero e importanza, rappresentano una delle colonie più ricche del territorio siciliano [2]. La grotta prosegue con una serie di gallerie e piccole sale a cupola e si interrompe in corrispondenza di un condotto occluso da materiale detritico [Grasso et al. I982, pp. 26 I-280; Schilirò et al. 2002, pp. 59-74; Spena et al. 20 I 3, p. I 7 I].

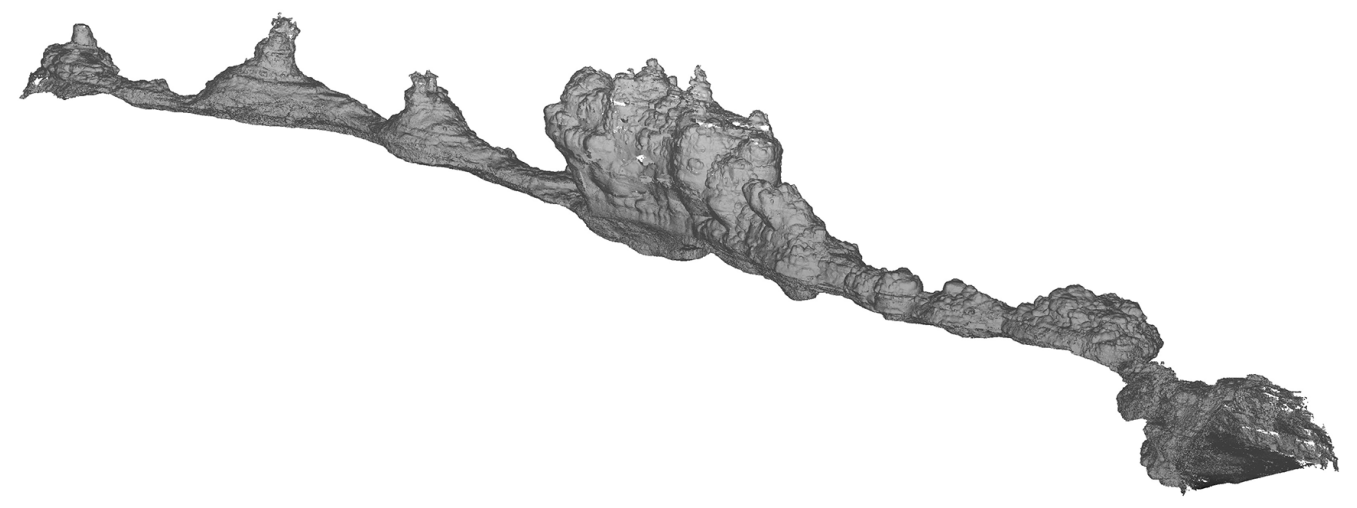

\section{Metodologia}

La metodologia messa a punto è stata finalizzata all'individuazione e alla verifica di un flusso di lavoro che, a partire da un modello numerico ottenuto attraverso un rilievo digitale integrato (laser scanning e fotogrammetria digitale automatizzata) e dal relativo modello poligonale (costituito da una densa mesh triangolare) sottoposto a un processo di ottimizzazione, giungesse alla creazione di un'esperienza di esplorazione virtuale del sito in esame, realizzata all'interno di un Game Engine. Uno degli obiettivi di questo progetto di fruizione virtuale è consistito nella sperimentazione del paradigma del Serious Game, per mezzo del 
quale l'esperienza di esplorazione virtuale non si limita a essere una semplice simulazione ludica immersiva, ma si caratterizza per la presenza di un forte contenuto pedagogico, legato alle modalità con cui l'utente è coinvolto emotivamente ed è spinto a interagire con l'ambiente virtuale [Airllo et al. 2019].
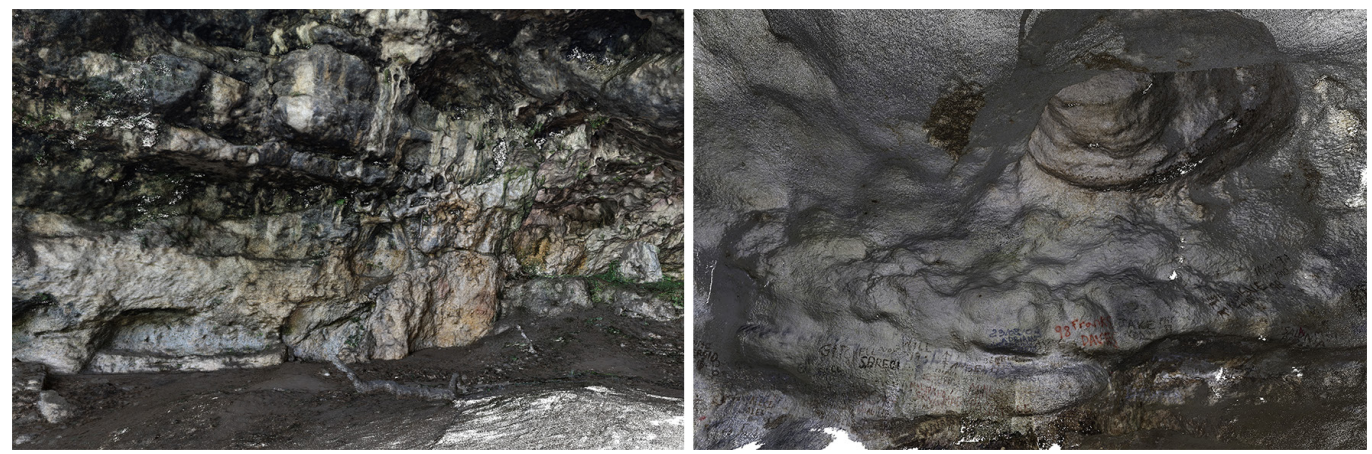

\section{Rilievo digitale}

La campagna di rilevamento ha avuto avvio con dei sopralluoghi che hanno permesso di acquisire consapevolezza delle caratteristiche della grotta (difficoltà d'accesso, morfologia, assenza di fonti di illuminazione naturali, impossibilità di introdurre luci artificiali per salvaguardare i chirotteri). Sulla base di queste caratteristiche si è deciso di procedere mediante laser scanner prediligendo una strumentazione di dimensioni ridotte, maneggevole e con un'alta velocità di acquisizione. Si è utilizzato il FARO Focus S70 a differenza di fase. Le riprese sono state effettuate al buio, con fotocamera disattivata, per non disturbare i chirotteri. Nello specifico, sono state eseguite 72 scansioni (fig. 3) con sufficiente grado di sovrapposizione in modo tale da facilitare l'allineamento successivo.

Le scansioni sono state processate nel software SCENE, generando una nuvola di punti di circa un miliardo e mezzo di punti (privi di informazione cromatica) con un errore medio di $2 \mathrm{~mm}$ (fig. 4).

Le scansioni dell'antro e dell'ultima sala della grotta [3] sono state integrate mediante tecniche SfM (Structure from Motion) utilizzando una fotocamera Canon EOS 70D. II dataset dell'antro consta di circa 1550 foto, mentre quello dell'ultima sala è costituito da 853 foto. I dataset fotografici sono stati elaborati tramite Agisoft Metashape, generando due nuvole di punti: quella dell'antro consta di circa 100 milioni di punti, mentre la nuvola dell'ultima sala è costituita da circa 150 milioni di punti (fig. 5).

Dopo essere stata georeferenziata, la nuvola fotogrammetrica è stata confrontata con quella ottenuta da laser scanner per valutare il grado di adesione tra le parti (fig. 6).

L'analisi ha mostrato che l'errore medio è generalmente inferiore a $5 \mathrm{~mm}$. Sono state rilevate deviazioni maggiori tra le nuvole (parti rosse in figura), ma in realtà sono dovute all'assenza di dati nella nuvola di punti del laser scanner. Sulla base di questo confronto, e considerando inoltre che il modello fotogrammetrico presenta un dato cromatico notevolmente accurato, si è scelto di sostituire la nuvola di punti da laser scanner con quella fotogrammetrica.

\section{Workflow per l'ottimizzazione e il texture mapping della mesh}

II modello numerico completo è stato convertito in mesh attraverso il software SCENE. Questa operazione è avvenuta per piccole porzioni (più facilmente gestibili), ognuna delle quali è costituita da un numero di poligoni dell'ordine di 6 milioni. Le porzioni di mesh così ottenute sono estremamente complesse e costituite da un numero di facce troppo elevato 
Fig. 6. Confronto fra la nuvola di punti fotogrammetrica e quella ottenuta dal laser scanner.
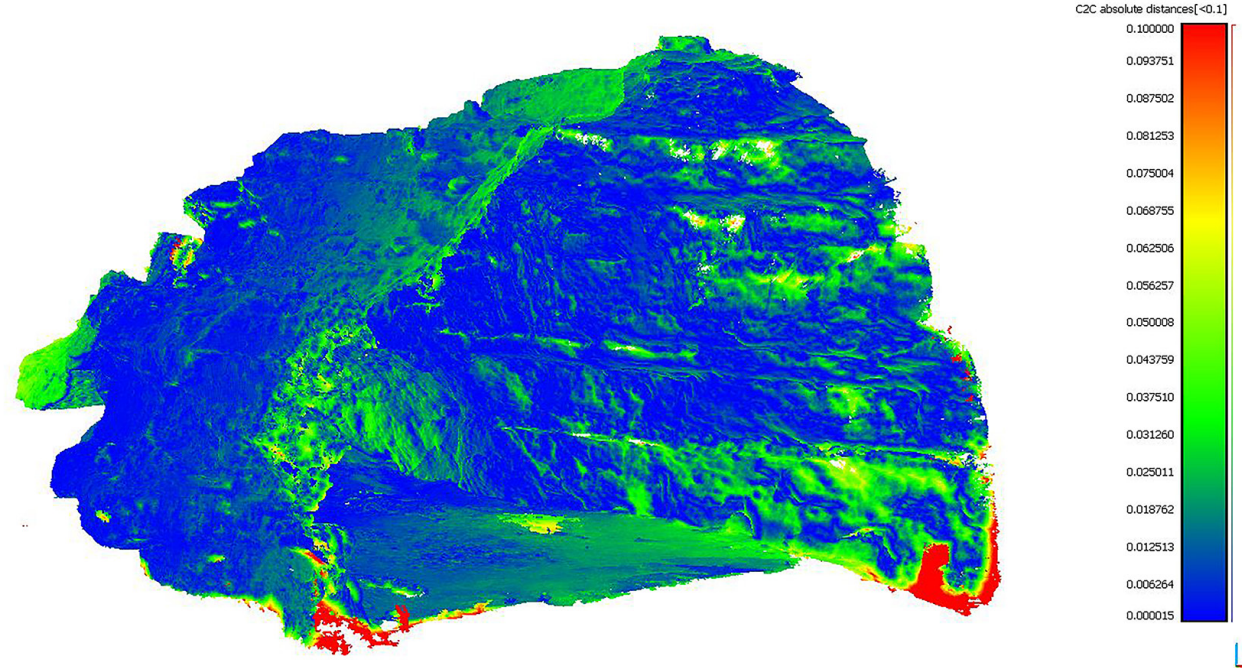

per essere gestito in virtual reality, ed è quindi necessario ottimizzarle.

L'ottimizzazione si basa essenzialmente su un procedimento di ridefinizione della topologia del modello, operazione che viene definita retopologia. Modificare la topologia di oggetti tridimensionali significa essenzialmente ridurre il numero delle facce (così da avere solo quelle strettamente necessarie) e modificare la loro geometria triangolare in quadrangolare, più facilmente gestibile. II software utilizzato per retopologizzare le mesh è stato Zbrush [4] (fig. 7).

Per recuperare il dettaglio di rugosità delle superfici triangolari (simulandone la complessità senza però la necessità di mantenere il modello poligonale con un alto livello di dettaglio) è stata effettuata una mappatura UV (che permette di applicare le texture al modello tridimensionale) e quindi è stata estrapolata una normal map. L'esito di questo processo è una superficie semplificata, e alleggerita, priva però di informazione cromatica, per ottenere la quale si è utilizzato Quixel, un programma integrato con Photoshop, che contiene una libreria di texture molto vasta.
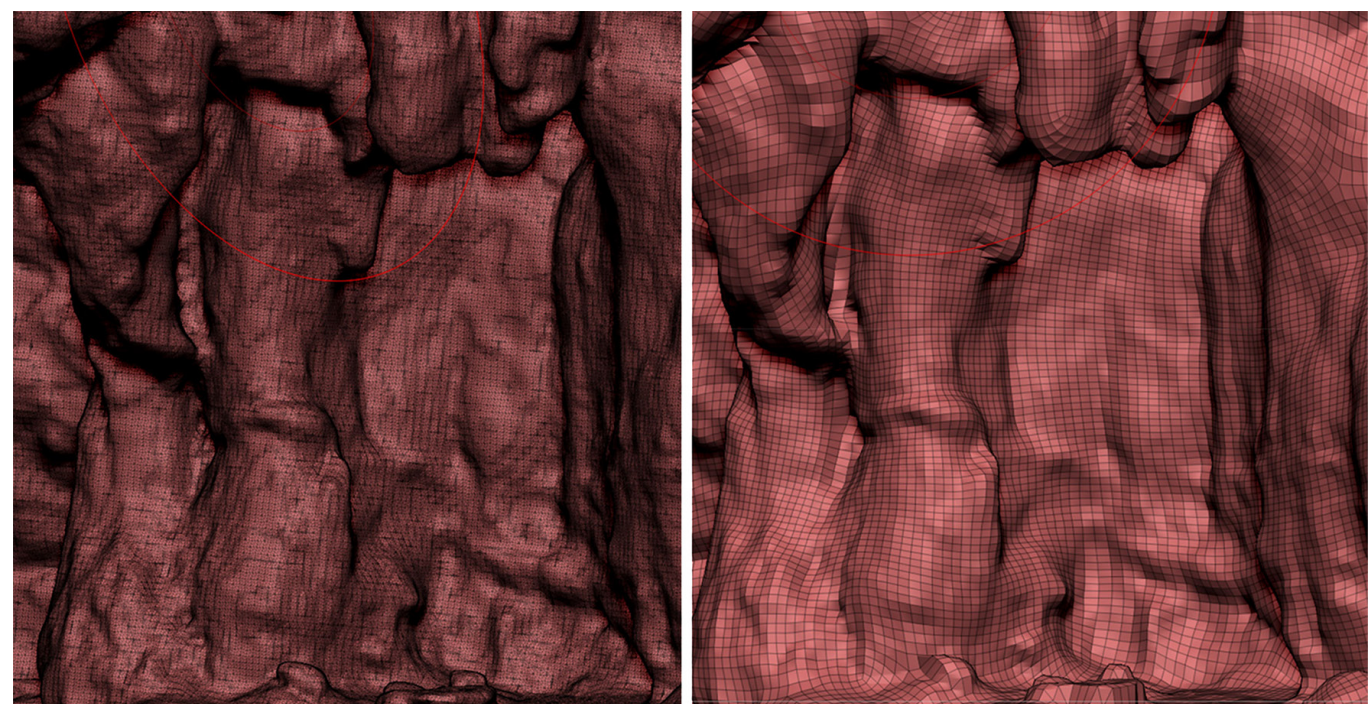


\section{Il progetto di fruizione virtuale: dall'ideazione alla realizzazione}

Il primo obiettivo che la simulazione virtuale ha inteso raggiungere è stato quello di rendere visitabile l'intera grotta in tutta la sua estensione. II secondo obiettivo è stato quello di associare dei metadati all'oggetto di studio, così da raccontare la sua morfologia, l'ecosistema che esso accoglie (con particolare riferimento alla colonia di chirotteri e ai fattori di rischio a cui essa è sottoposta), la sua genesi geologica e i resti fossili rinvenuti nelle pareti del talus. II modello della grotta ottimizzato è stato importato sul software Unreal Engine, all'interno del quale è stata realizzata la simulazione virtuale e le interazioni tra esploratore/giocatore e ambiente.
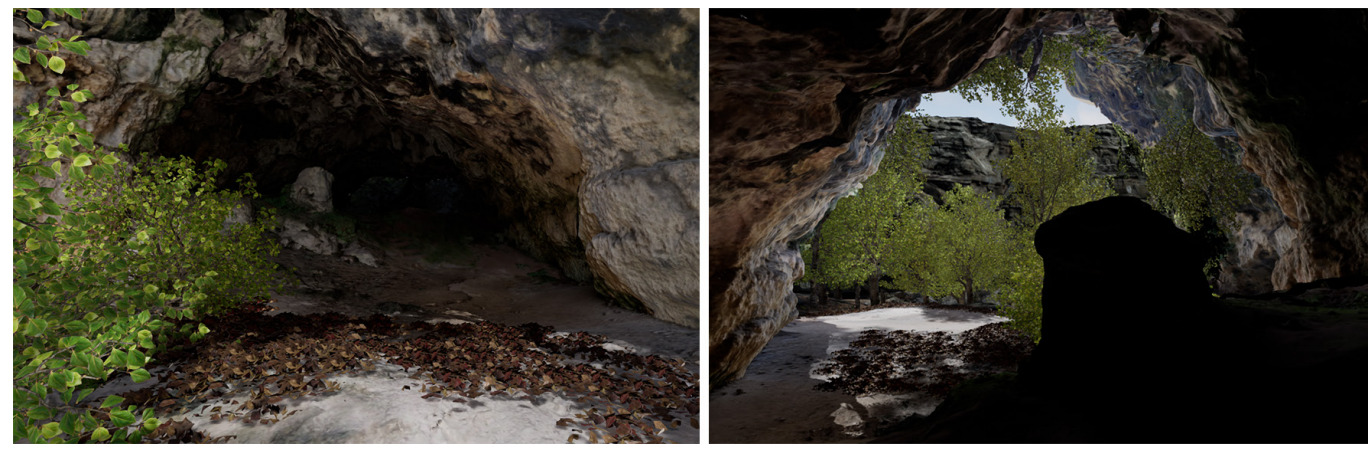

L'esperienza virtuale inizia dall'antro (fig. 8), illuminato dalla luce solare diretta e affacciato su uno sfondo naturale che richiama la vista reale sulla valle del Calcinara, con il declivio roccioso ricoperto da una fitta vegetazione.

A rendere l'esperienza immersiva anche da un punto di vista sensoriale contribuiscono i suoni della natura e lo scroscio delle acque. II visitatore è accompagnato da una voce narrante, che dà informazioni sulla storia e le caratteristiche della grotta, come pure sugli elementi interattivi presenti lungo il percorso. Procedendo verso l'interno degli ambienti ipogei, la luce naturale diminuisce fino a lasciare la grotta nella più completa oscurità. Per proseguire, l'utente si servirà dunque di una torcia che troverà lungo il suo cammino e che potrà afferrare e portare con sé per illuminare fiocamente gli ambienti più interni.
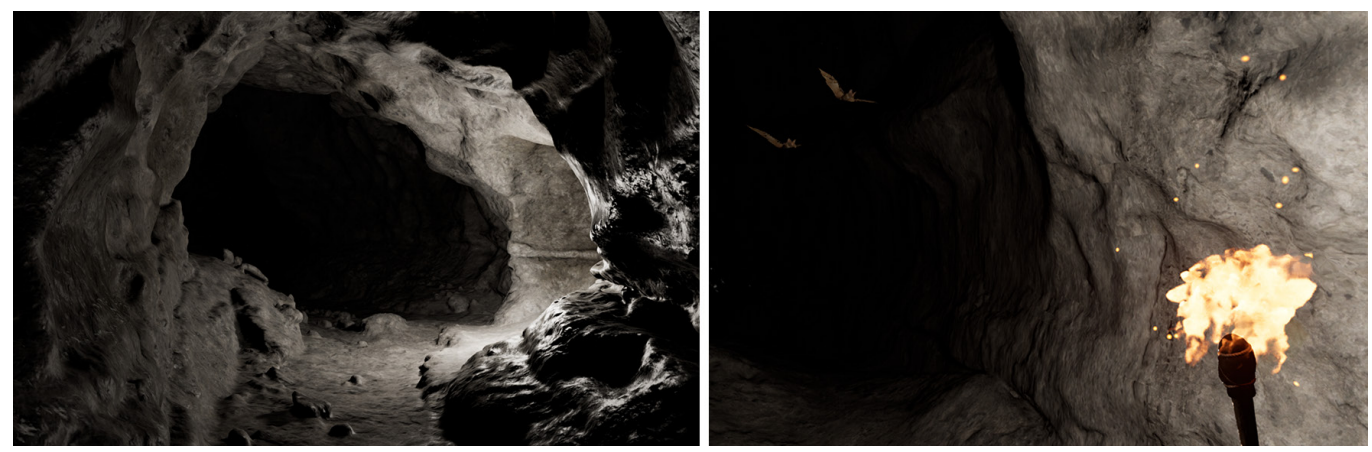

Il viaggio nella penombra procede fino a raggiungere la grande Sala del Guano, con l'alto soffitto popolato dalla colonia di pipistrelli. Qui l'atmosfera reale viene rievocata usando ancora una volta una componente visiva e una sonora: la prima si concretizza nella totale assenza della luce naturale e nella presenza di alcuni esemplari di pipistrelli in volo, mentre la seconda è determinata dalla possibilità di sentire riecheggiare, all'interno dell'enorme sala, lo stridio dei chirotteri nascosti negli anfratti del soffitto (fig. 9). 
Superata la "Sala del Guano", è possibile procedere ancora fino a raggiungere l'ultimo degli ambienti ipogei, dove la visita si conclude dinanzi al condotto occluso, mai scavato, oltre il quale potrebbero nascondersi altre sale finora inesplorate.

Tutte le interazioni allinterno della simulazione virtuale (come la torcia, i pannelli informativi, la voce narrante ecc.) sono state progettate in Unreal Engine utilizzando l'innovativo sistema Blueprint Visual Scripting, un sistema di scripting basato su un'interfaccia a nodi e capace di sostituire il complesso linguaggio di programmazione $\mathrm{C}++$ (fig. I0).
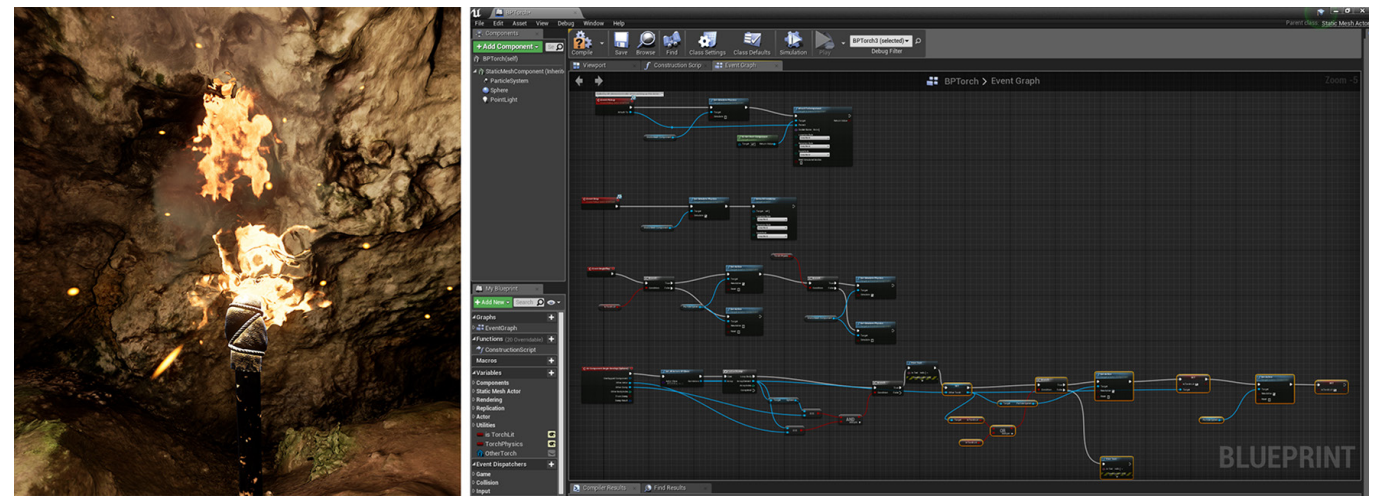

\section{Conclusioni}

La Grotta dei Pipistrelli è un luogo caratterizzato da una grande bellezza nonché da un'elevata rilevanza culturale, ma risulta inaccessibile a molte categorie di potenziali visitatori o studiosi, a causa della sua ubicazione in un ambiente non facilmente raggiungibile. Paradossalmente, la difficile accessibilità per alcune categorie di utenti non impedisce al sito di essere oggetto di una notevole pressione antropica; sono stati infatti registrati diversi fenomeni di vandalismo ai danni del delicato habitat naturale della chirotterofauna.

II processo di digitalizzazione si è posto l'obiettivo ambizioso di costruire un ambiente virtuale, fedele riproduzione di quello reale, che può essere fruito da tutte le categorie di utenti, limitando così l'accesso nelle sale più interne della grotta, dove la colonia di pipistrelli trova asilo. Questo approccio, tra l'altro, può offrire un valido esempio applicabile anche ad altri manufatti di alto valore storico, artistico o naturalistico che risultano difficilmente accessibili a causa della presenza di percorsi impervi o di condizioni di fragilità incompatibili con la fruizione diretta.

\section{Ringraziamenti}

Gli autori desiderano ringraziare il Dr. Filadelfo Brogna, responsabile del "Dipartimento Regionale Azienda Foreste Demaniali di Siracusa - UPA di Siracusa" e responsabile delle Riserve Naturali:Vendicari, Cavagrande del Cassibile, Pantalica/Valle dell'Anapo, per l'accesso alla Grotta, il prof. Rosario Grasso e la dott. Maria Teresa Spena per il supporto in grotta, la prof. Mariateresa Galizia e gli ingegneri Umberto Montedoro e Graziana D'Agostino per l'aiuto durante le fasi di rilievo.

\section{Note}

[I] Il cancello ha la funzione di impedire l'accesso ai curiosi e al contempo consentire il passaggio ai pipistrelli.

[2] Le colonie presenti nella Grotta sono di tipo riproduttivo.

[3] Si è scelto di integrare le scansioni con la tecnica fotogrammetrica solo in quelle zone in cui si era certi di non recare danni alla colonia di pipistrelli presenti nella grotta.

[4] Programma di grafica computerizzata che combina modellazione, texturizzazione e painting in 3D e 2,5D. 


\section{Riferimenti bibliografici}

Aiello Damiano, Basso Alessandro, Spena Maria Teresa, D'Agostino Graziana, Montedoro Umberto, Galizia Mariateresa, Grasso Rosario, Santagati Cettina (2019). The Virtual Batcave: a project for the safeguard of a UNESCOWHL fragile ecosystem. In Int Arch. Photogramm. Remote Sens. Spatial Inf. Sci., vol. XLII-2/W9, pp. I7-24.

Aiello Damiano, Fai Stephen, Santagati Cettina (2019). Virtual museums as a means for promotion and enhancement of Cultural Heritage. In Int. Arch. Photogramm. Remote Sens. Spatial Inf. Sci., vol. XLII-2MW I5, pp. 33-40.

Alessandri Luca, Baiocchi Valerio, Del Pizzo Silvio, Rolfo Mario Federico, Troisi Salvatore (2019). Photogrammetric Survey with Fisheye Lens for the Characterization of the la Sassa Cave. In ISPRS-International Archives of the Photogrammetry, Remote Sensing and Spatial Information Sciences, vol. 422, pp. 25-32.

Alessandri Luca, Baiocchi Valerio, Del Pizzo Silvio, Di Ciaccio Fabiana, Onori Matteo, Rolfo Mario Federico, Troisi Salvatore (2019). Three-dimensional survey of Guattari cave with traditional and mobile phone cameras. In Int. Arch. Photogramm. Remote Sens. Spatial Inf. Sci., vol. XLII-2/WII, pp. 37-4I.

Bolognesi Cecilia, Aiello Damiano (2019). From Digital Survey to a Virtual Tale:Virtual Reconstruction of the Convent of Santa Maria delle Grazie in Milan. In Bolognesi Cecilia, Santagati Cettina. Impact of Industry 4.0 on Architecture and Cultural Heritage. Hershey, PA: IGI Global. pp. 49-75.

Buchroithner Manfred, Milius Jeannette, Petters Christin (20I I). 3D surveying and visualization of the biggest ice cave on earth. Proceedings of 25th International Cartographic Conference. Paris, France.

Cabrelles López Miriam, Lerma García José Luis (2013). Documentación 3D de abrigos rupestres a partir de láser escáner y de procesos fotogramétricos automatizados. In Virtual Archaeology Review, vol. 4(8), pp. 64-68.

De Vos Peter, De Rijk Melissa (2019). Virtual reconstruction of the birthplace of Rembrandt Van Rijn: from historical research over 3D modeling towards virtual presentation. In Int. Arch. Photogramm. Remote Sens. Spatial Inf. Sci., vol. XLII-2/WI 5, pp. 397 404.

Fabbri Stefano, Sauro Francesco, Santagata Tommaso, Rossi Guido, De Waele lo (2017). High-resolution 3-D mapping using terrestrial laser scanning as a tool for geomorphological and speleogenetical studies in caves: An example from the Lessini mountains (North Italy). In Geomorphology, vol. 280, pp. I 6-29.

Grasso Mario, Lentini Fabio (1982). Sedimentary and tectonic evolution of the eastern Hyblean plateau (southeastern Sicily) during Late Creataceous to Quaternary time. In Paleogeography Palaeoclimatology Palaeoecology, vol. 39, pp. 26 I-280.

Mohammed Oludare Idrees, Pradhan Biswajeet (2016). A decade of modern cave surveying with terrestrial laser scanning: A review of sensors, method and application development. In International Journal of Speleology, vol. 45(I), p. 8.

Nocerino Erica, Nawaf Mohamad M., Saccone Mauro, Ellefi Mohamed B., Pasquet Jérôme, Royer Jean-Philip, Drap Pierre (20 I 8). Multi-camera system calibration of a low-cost remotely operated vehicle for underwater cave exploration. In International Archives of the Photogrammetry, Remote Sensing \& Spatial Information Sciences, vol. 42(I), pp. 329-337.

Nocerino Erica, Menna Fabio, Farella Elisa Mariarosaria, Remondino Fabio (2019). 3D virtualization of an underground semisubmerged cave system. In Int. Arch. Photogramm. Remote Sens. Spatial Inf. Sci., vol. XLII-2M I 5, pp. 857-864.

Paganini Paolo, Fingolo Margherita, Facco Lorenzo, Ceccato Alessio, Breganze Carlo, Cezza Marcello (20I I). Tra realtà virtuale e rilievi 3D ad alta risoluzione. In Veneto Geologi, pp. 2I-25.

Schilirò Francesco, Ruggieri Rosario, Cannata Andrea (2002). Necropoli di Pantalica: Carsismo e processi cinematici sul versante nord-orientale del Torrente Calcinara. In Speleologia Iblea, vol. I0, pp. 59-74.

Spena Maria Teresa, Allegra Filosico Manuela, Brogna Filadelfo, Dipasquale Costanza, Puma Antonio, Grasso Rosario, Agnelli Paolo (20 I3). I chirotteri della Grotta dei Pipistrelli (SR): un unicum nella Sicilia sud-orientale. In Atti della Società dei Naturalisti e Matematici di Modena, vol. I44, p. I7I.

Trizio Ilaria, Brusaporci Stefano, Luigini Alessandro, Ruggieri Andrea, Basso Alessandro, Maiezza Pamela, Tata Alessandra, and Giannangeli Alessandro (2019). Experiencing the inaccessible. a framework for virtual interpretation and visualization of remote, risky or restricted access heritage places. In Int. Arch. Photogramm. Remote Sens. Spatial Inf. Sci., vol. XLII-2MVI5, pp. | $17|-1| 78$.

\section{Autori}

Damiano Antonino Angelo Aiello, Università di Catania, damianoaiello@gmail.com Cettina Santagati, Università di Catania, cettina.santagati@dau.unict.it

Per citare questo capitolo: Preservare la memoria: dal rilievo digitale alla realtà virtuale per la conservazione del patrimonio naturale a rischio/ Preserving memory: from digital survey to virtual reality for the conservation of natural heritage at risk. In Arena A., Arena M., Brandolino R.G. Colistra D., Ginex G., Mediati D., Nucifora S., Raffa P. (a cura di). Connettere. Un disegno per annodare e tessere. Atti del $42^{\circ}$ Convegno Internazionale dei Docenti delle Discipline della Rappresentazione/Connecting. Drawing for weaving relationships. Proceedings of the 42th International Conference of Representation Disciplines Teachers. Milano: FrancoAngeli, pp. 151 0- 1527. 


\title{
Preserving Memory: from Digital Survey to Virtual Reality for the Conservation of Natural Heritage at Risk
}

\author{
Damiano Antonino Angelo Aiello \\ Cettina Santagati
}

\section{Abstract}

This paper investigates the possibilities of Virtual Reality for the preservation of natural heritage at risk. The experimentation was conducted on the Grotta dei Pipistrelli, a Sicilian cave in the Nature Reserve of Pantalica (SR) that is subject to anthropic pressure which is almost certainly threatening the precious biodiversity of the site. The project involved the systematic collection of relevant data, including morphology, geological and material characteristics, and fauna, with the aim of supporting future studies and creating a database that conserves the memory of this site and is able to communicate it through innovative media. The geometry of the cave was documented through the combined use of laser scanning and photogrammetric techniques, and the resulting numerical model was used to develop a prototype for the virtual exploration of the cave, so that anyone could experience this unique treasure without compromising the site further with actual human presence.

Keywords

digital survey, digital natural heritage, virtual reality, serious game, cave.

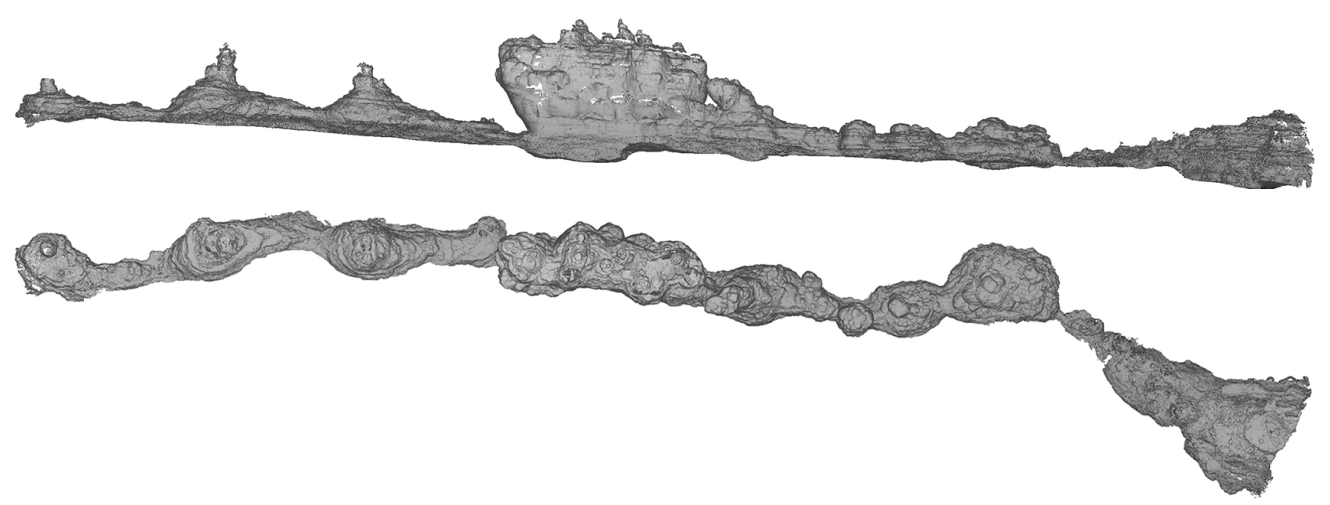




\section{Introduction}

Cultural heritage, which in the broad sense of the term encompasses architecture as well as natural and landscape heritage, is extremely fragile and often finds itself teetering between memory and oblivion. By memory, we do not simply intend an arid record of univocal information and notions, but also the obscure, ambiguous, elusive and volatile aspects that are inherent with the persistent risk of extinction. Heritage recollection therefore represents a challenge and a stimulus for humanity, which is bound by duty and driven by need to investigate, interpret, and find new and increasingly effective ways to share comprehension and insight while protecting it from its own fragility.

The experimentation described herein applies the above principles to the Grotta dei Pipistrelli site located in Sicily in the Natural Reserve of Pantalica (SR), which has been included in the UNESCOWHL since 2005. The precious biodiversity of the cave, which is home to one of the most important bat breeding colonies in the Mediterranean, risks being compromising by consistent anthropic pressure.

The project aims to create a database from the systematic collection of information relating to the morphology, the geological and material characteristics, and the species that inhabit the cave, in order to preserve the memory of the site and facilitate its communication through innovative media, as well as to supplement potential future research.

The research team integrated laser scanning and photogrammetric technologies to derive a numerical model of the analysed environment that can support a range of differing interdisciplinary studies (an example might be to associate sensor data with the model to allow real-time monitoring of the environmental conditions).

Research activity was also focused on developing a prototype for experiencing the cave through Virtual Reality, allowing anyone the possibility of simulating a visit to this unique and not easily accessible location, without risking further anthropic pressure on the actual site.

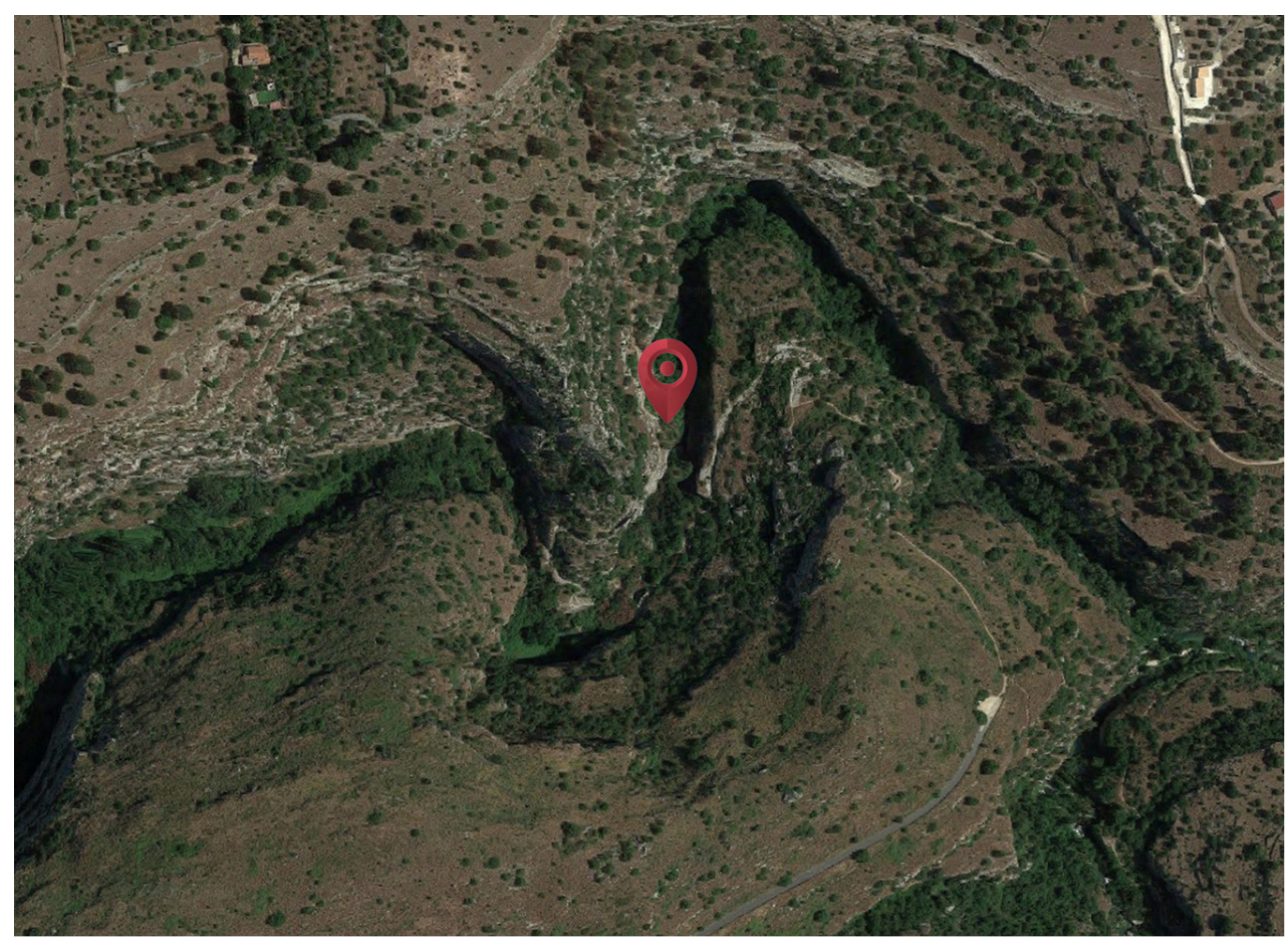




\section{Related works}

Surveying natural heritage presents unique challenges peculiar to each location. Hypogeal environments for instance often involve complex morphologies and very little available light, among other things. Surveys inside caves and underground cavities have to date been generally performed using traditional techniques, with seemingly little interest in innovative approaches such as digital surveying, perhaps due to the new technical skills that must in some way be acquired. Digital surveying through laser scanning and photogrammetric techniques is, however, the most effective strategy in terms of being able to provide extremely accurate information in a relatively short time [Buchroithner et al. 20 I I; Mohammed Oludare et al. 20। 6, p. 8; Fabbr, et al. 2017, pp. 16-29].

In recent years, numerous research efforts have focused on the combination of different surveying techniques to obtain better results [Cabrelles López et al. 2013, pp. 64-68], or on the use of different instruments such as multi-camera systems [Nocerino et al. 2018, pp. 329-337], fisheye lenses [Alessandri et al. 2019, pp.25-32], or mobile phone cameras to capture very narrow and complex spaces [Alessandri et al. 20I9, pp. 37-4I].

The substantial databases derived from digital survey form an excellent platform for the preservation of the memory and in-depth analysis of a location, as well as for creating VR environments that can reveal less accessible locations such as hypogeal environments [Nocerino et al. 2019, pp. 857-864; Paganini et al. 201 I, pp. 21-25].

In this sense, Virtual Reality helps overcome physical barriers by allowing virtual tours and interaction with sites that are perhaps distant or prohibited for safety and conservation reasons [De Vos et al. 20 I9, pp. 397-404; Trizio et al. 2019, pp. I I 7 I - I I78].

The effectiveness of these virtual simulations can be enhanced through the serious game paradigm, where gaming elements are introduced for educational purposes rather than mere recreation, given its potential to heighten curiosity and stimulate involvement [Aiello et al. 2019, pp. 33-40; Bolognesi et al. 2019, pp. 49-75].

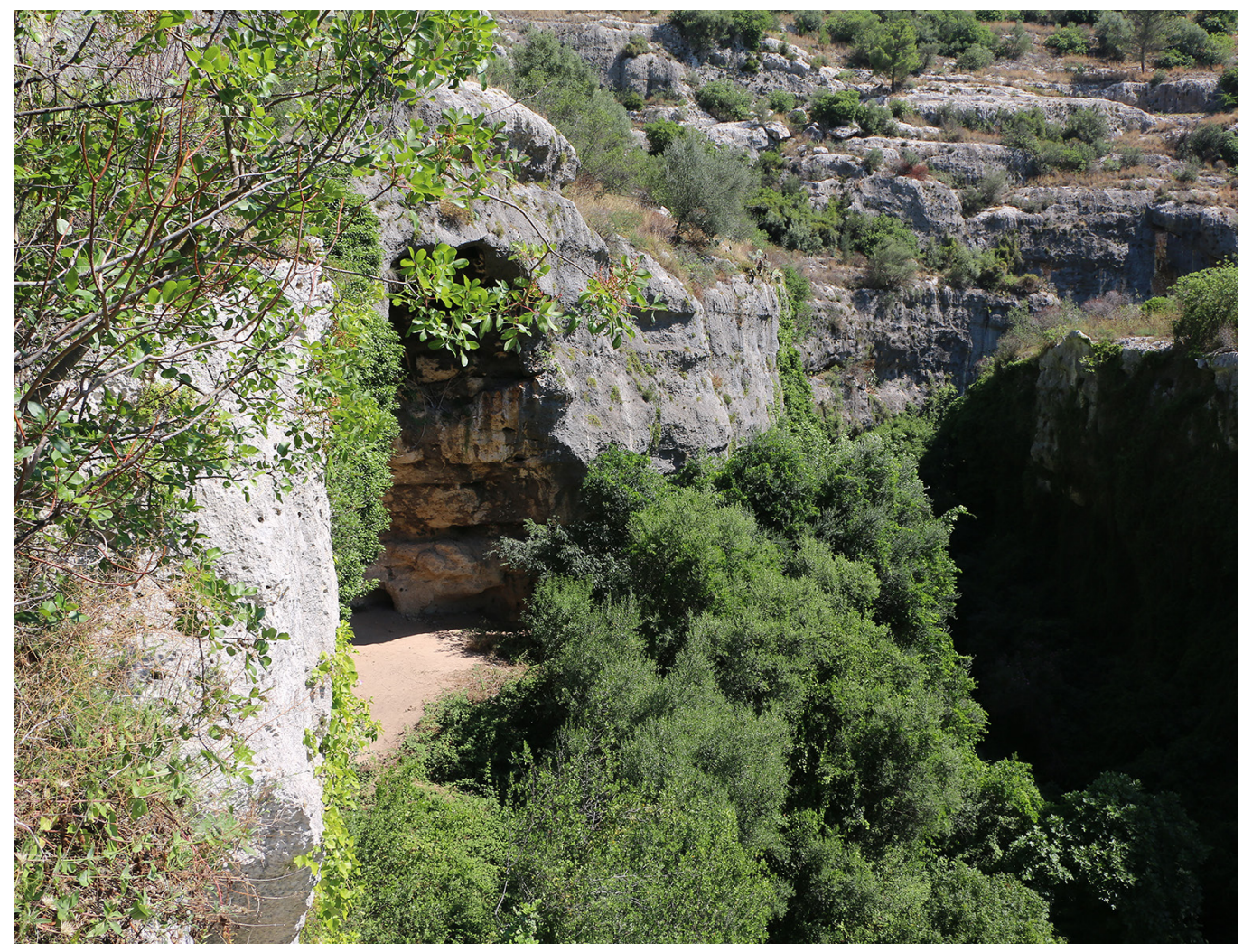




\section{The Grotta dei Pipistrelli in Pantalica}

The Grotta dei Pipistrelli is an extremely important site for the protection and conservation of Sicilian bats. The cave, one of the largest karst cavities of the Pantalica, valle dell'Anapo e torrente Cavagrande Nature Reserve, opens on a rocky wall overhanging the Calcinara stream (figs. I, 2).

The deep horizontal underground environment has a passable stretch of about 260 metres in length. The access room to the cave, called talus, is $18 \mathrm{~m}$ wide, $28 \mathrm{~m}$ long and about 15 $\mathrm{m}$ high, and funnels into a small conduit $12 \mathrm{~m}$ long that terminates in a gate that leads to

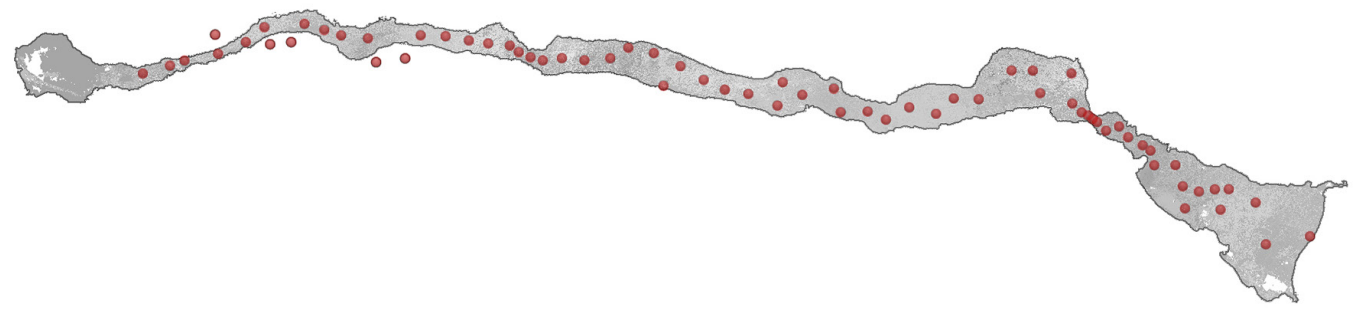

a large room about $22 \mathrm{~m}$ long and II $\mathrm{m}$ high. The latter is followed by another passage with phreatic morphologies on the walls and ceiling (such as megascallops, domes and side grooves), which leads to the largest cavern in the underground complex called La Sala del Guano, with a vault consisting of three intersecting domes at a maximum height of $30 \mathrm{~m}$ and a length of about $40 \mathrm{~m}$. Here, different species of bats find refuge in one of the richest

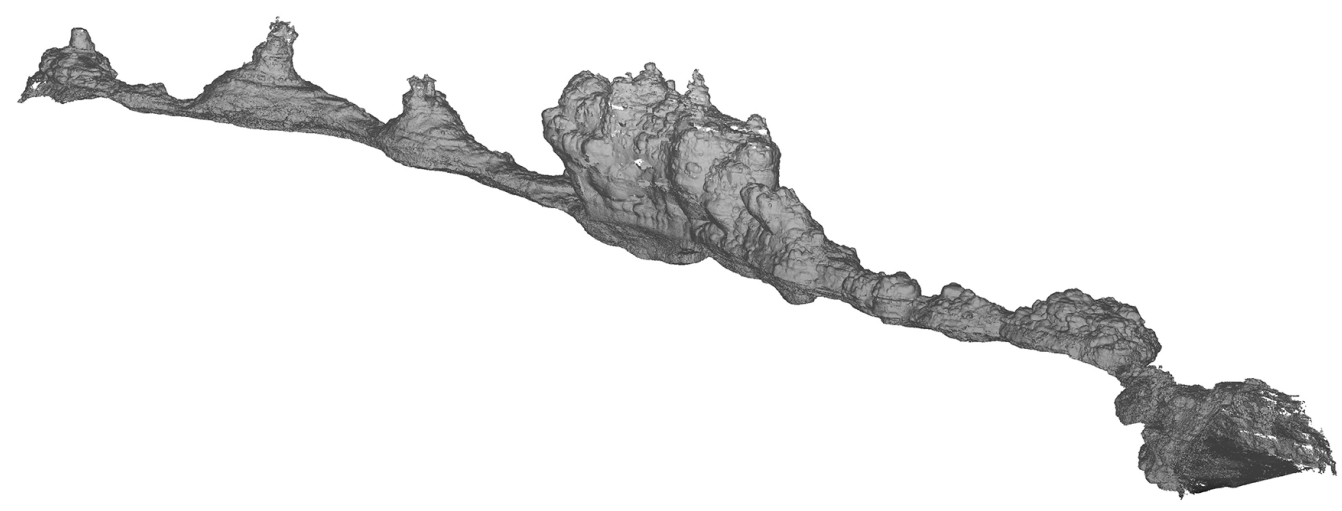

colonies in the Sicilian territory in terms of magnitude and importance [I].The cave continues with a series of galleries and small domed rooms, finally ending in a passage that is blocked with debris [Grasso et al. 1982, pp. 26I-280; Schilirò et al. 2002, pp. 59-74; Spena et al. 20|3, p. I7I]. 


\section{Methodology}

The methodology developed to identify and verify the workflow begins with a numerical model obtained through an integrated digital survey (laser scanning and automated digital photogrammetry) and corresponding polygonal model consisting of a dense triangular mesh that must be optimized to allow fluid exploration of the site inside a virtual game engine. Indeed, one of the objectives of this VR project was to experiment with the notion of the Serious Game paradigm, in which virtual exploration is not intended simply for immersive play, but is characterized by strong pedagogical content aimed at involving and encouraging the user to interact with the virtual environment [Aiello et al. 2019, pp. 17-24].
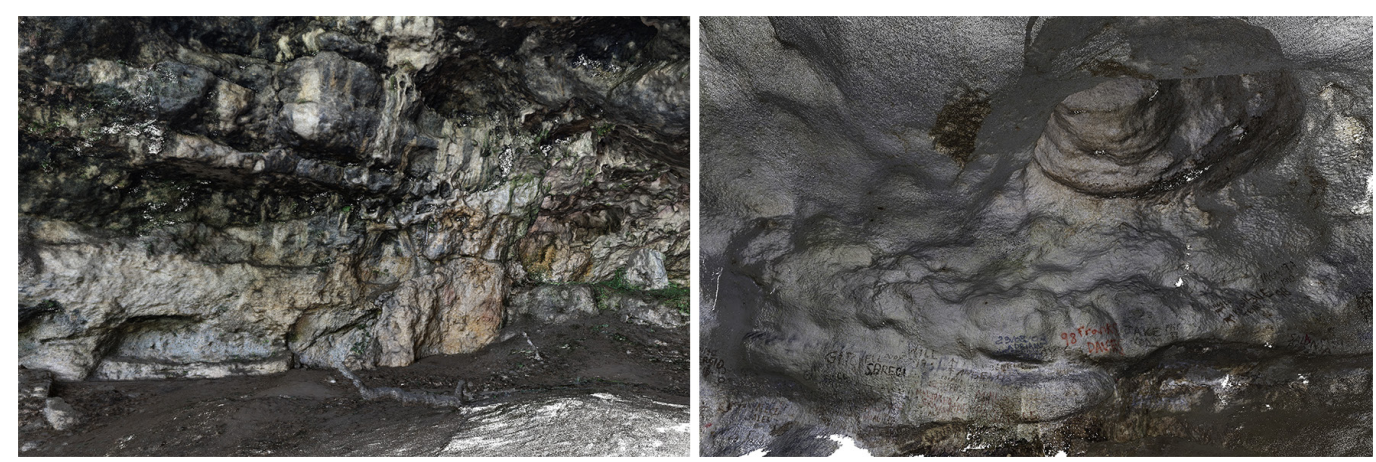

\section{Digital Survey}

The survey campaign began with site visits to gain familiarity with the characteristics of the cave in terms of access, morphology, scarcity of natural light and the impossibility to introduce artificial light to protect the bats. It was decided to acquire the cave using the FARO Focus S70 laser scanner thanks to its small dimensions, easy manageability, and high acquisition speed. The scans were acquired without texture to avoid disturbing the bats. 72 scans were performed (fig. 3), with sufficient overlap to facilitate the subsequent alignment phase.

The scans were processed using SCENE software to generate a point cloud of about one and a half billion points (without colour information), with an average error of $2 \mathrm{~mm}$ (fig. 4). The scans of the cave entrance and the last room were integrated using SfM (Structure from Motion) techniques using a Canon EOS 70D camera [2]. The dataset of the entrance consists of about 1550 photos, while that of the last room consists of 853 photos.

The photographic datasets were processed using Agisoft Metashape to generate two point clouds: one for the entrance and one for the last room, consisting of about 100 million and I 50 million points, respectively (fig. 5).

After being geo-referenced, the photogrammetric clouds were compared with ones obtained from laser scanning to assess the degree of adherence between the parts (fig. 6). The analysis revealed an average error of generally less than $5 \mathrm{~mm}$. Larger deviations between the clouds were found (red parts in the figure), but these were largely due to the absence of data in the laser scanner point cloud. Based on this comparison and considering also that the photogrammetric models possessed remarkably accurate chromatic data, we decided to replace portions of the laser scanner point cloud with the photogrammetric counterparts. 
Fig. 6. Comparison between the photogrammetric and the laser scanner point clouds.

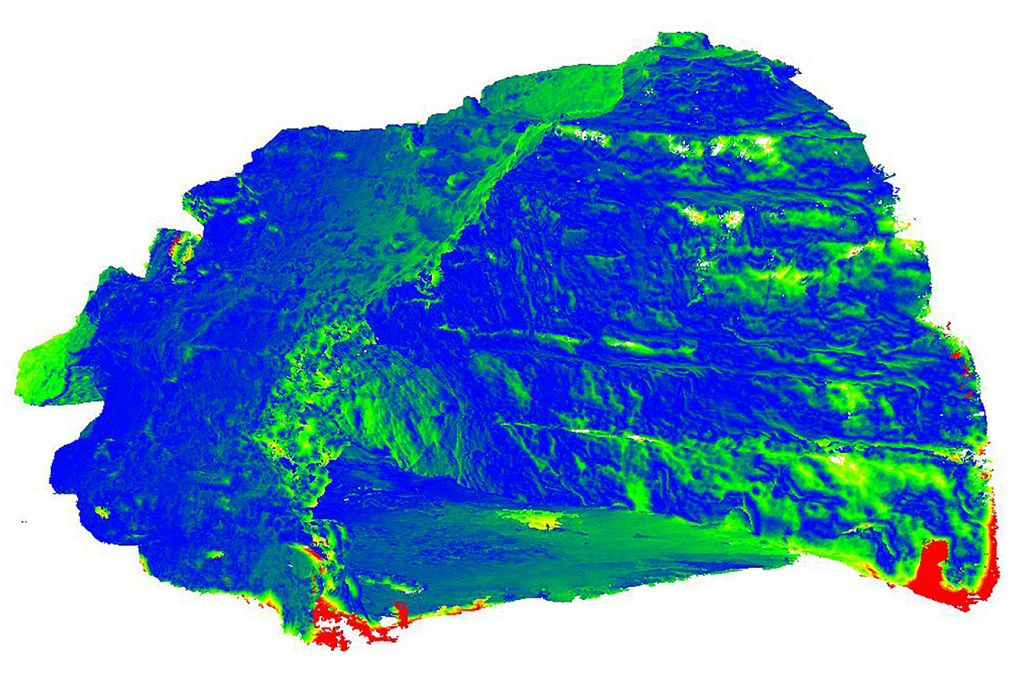

\section{Workflow for mesh optimization and texture mapping}

Conversion of the numerical model into a mesh using the SCENE software package was performed in smaller, more manageable portions of 6 million polygons at a time, with subsequent optimization to reduce the number faces the virtual reality engine must process. The ZBrush [3] software was used to produce the optimized model by redefining the topology of three-dimensional objects, essentially reducing the number of faces to only those strictly necessary and transforming the triangular geometry into a more manageable quadrangular geometry (fig. 7). Surface texture (including roughness detail) was then applied to the model using a UV mapping process followed by the subsequent extrapolation of a normal map. The final process involved adding colour information using the Quixel plugin for Photoshop, which has a very large texture library.
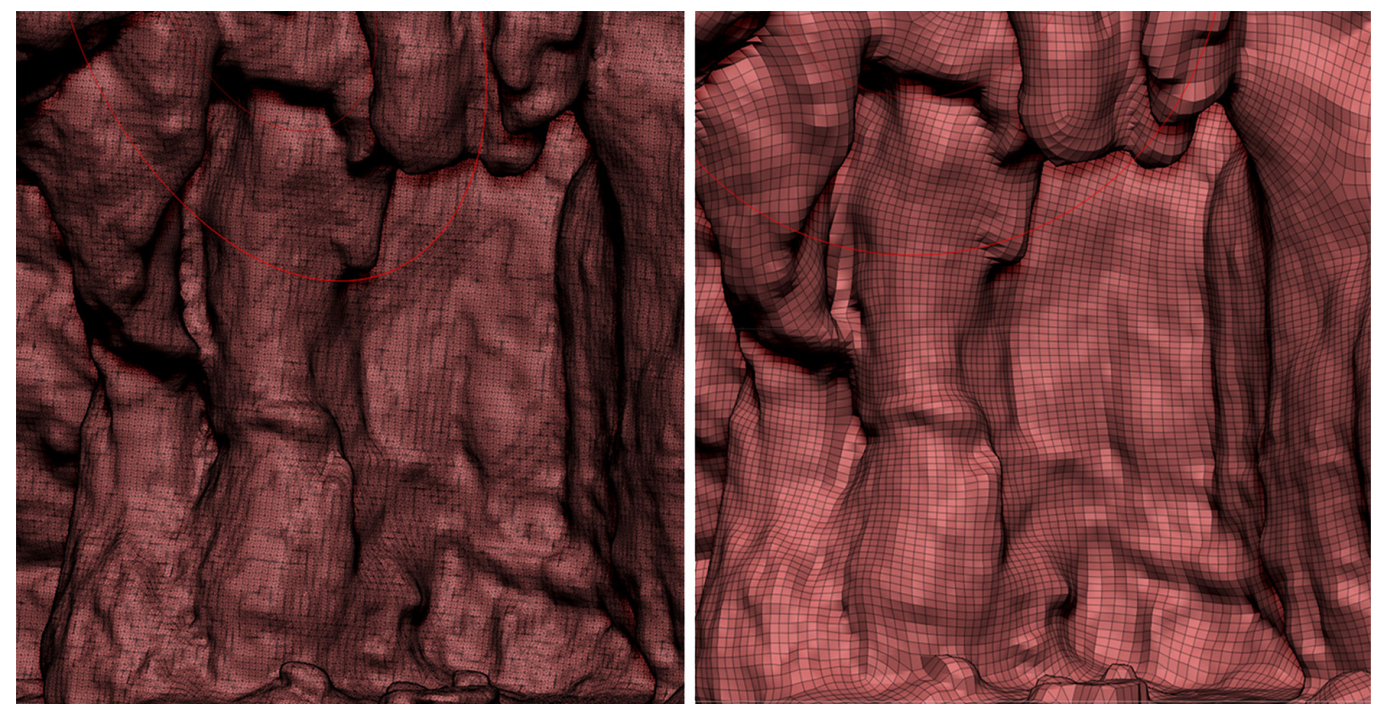


\section{The virtual fruition project: from conception to development}

The first objective of the virtual simulation was to render the entire cave explorable, and the second was to associate metadata with information such as morphology, the prevalent ecosystem (with particular reference to the bat colony and associated risk factors), geological genesis, and fossil remains found in the walls of the talus. The optimized cave model was then imported into the Unreal Engine game engine in order to build a full virtual environment complete with interactions between the visitor and the environment.

The virtual experience begins at the entrance (fig. 8), illuminated by direct sunlight and overlooking a natural background reminiscent of the real view of the Calcinara valley, with the rocky slope covered by vegetation.
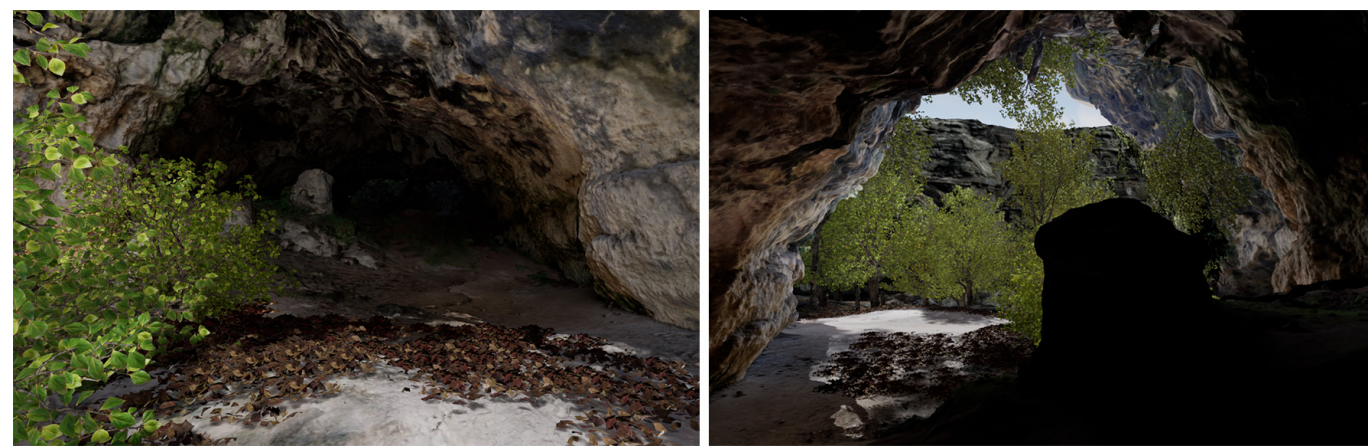

The sounds of nature and the flowing stream complement the sensory experience, and a narrative voice provides information concerning the history and characteristics of the cave, as well as about interactive elements one encounters along the tour. As we progress into the hypogeal environment, the natural light decreases until the cave becomes pitch black, and the user must activate a torch that he or she finds previously to somewhat illuminate the innermost rooms. The virtual journey proceeds in partial darkness until reaching the Sala del Guano, with its high ceiling and bat population. Here again, complementary audio and video provide a faithful simulation of the cavern, with dim lighting, flying bats and loud screeching from the ceiling (fig. 9).

Having crossed into Sala del Guano, it is possible to continue walking to the last of the
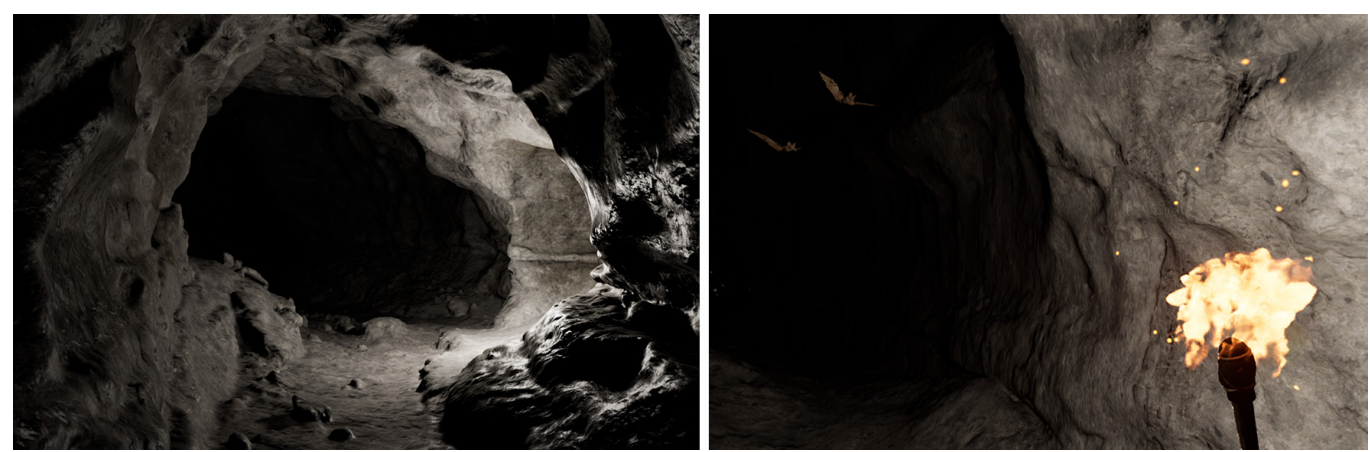

hypogeal rooms, where the tour ends in front of the occluded duct that was never cleared, and beyond which other unexplored rooms may hide.

All the interactions inside the virtual environment (such as the torch, the information panels, the narrator, etc.) were built in Unreal Engine using the innovative Blueprint Visual Scripting system based on a node interface, instead of the more tedious $\mathrm{C}++$ programming language (fig. I0). 


\section{Conclusion}

The Grotta dei Pipistrelli is a place of great beauty and high cultural relevance, situated in a location that many visitors and scholars would find difficult or impossible to access. In some respects, this can only be considered a boon as the site remains subject to considerable anthropic pressure despite its inaccessibility, and certain episodes of vandalism have unfortunately also been recorded in this delicate natural habitat of the bats.

The digitization process achieved the ambitious goal of building a faithful replica of the real site that can be enjoyed by anyone without the need for actual human presence in the innermost caverns, which would only compromise the fragile stability of this sanctuary. This approach must certainly represent a valid and viable alternative for countless other artefacts of high historical, artistic or naturalistic value that cannot or should not be accessed due to significant risks to conservation, or safety, or both.
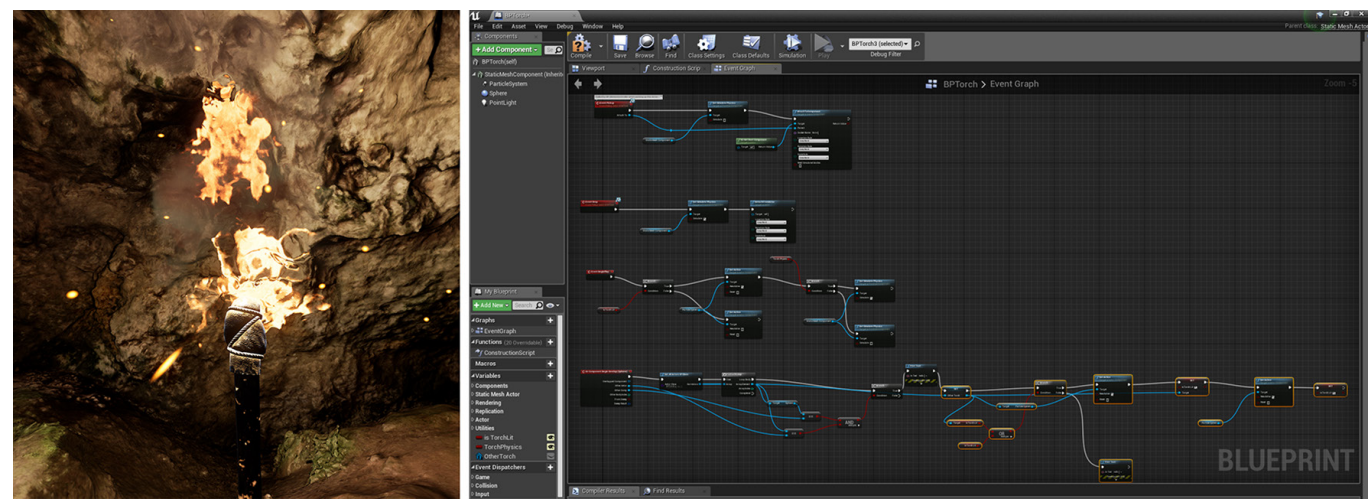

\section{Acknolodgement}

The authors would like to thank Dr. Filadelfo Brogna, head of the Dipartimento Regionale Azienda Foreste Demaniali di Siracusa - UPA di Siracusa and head of Natural Reserves:Vendicari, Cavagrande del Cassibile, Pantalica/Valle dell'Anapo, for the access to the Cave, Prof. Rosario Grasso and Dr. Maria Teresa Spena for the support in the cave, Prof. Mariateresa Galizia and the engineers Umberto Montedoro and Graziana D'Agostino for the help during the surveying phases.

\section{Notes}

[I]The bats of La Grotta dei Pipistrelli are part of a breeding colony.

[2] It was more appropriate to integrate the laser scanning technique with the photogrammetry in the areas of the cave where it was certain the colony of bats would not be disturbed or any of their habitat damaged.

[3] Computer graphics software that combines modelling, texturizing and painting in 3D and 2.5D

\section{References}

Aiello Damiano, Basso Alessandro, Spena Maria Teresa, D’Agostino Graziana, Montedoro Umberto, Galizia Mariateresa, Grasso Rosario, Santagati Cettina (2019). The Virtual Batcave: a project for the safeguard of a UNESCO WHL fragile ecosystem. In Int. Arch. Photogramm. Remote Sens. Spatial Inf. Sci., vol. XLII-2/N9, pp. 17-24.

Aiello Damiano, Fai Stephen, Santagati Cettina (2019). Virtual museums as a means for promotion and enhancement of Cultural Heritage. In Int. Arch. Photogramm. Remote Sens. Spatial Inf. Sci,, vol. XLII-2/W I5, pp. 33-40.

Alessandri Luca, Baiocchi Valerio, Del Pizzo Silvio, Rolfo Mario Federico, Troisi Salvatore (2019). Photogrammetric Survey with Fisheye Lens for the Characterization of the la Sassa Cave. In ISPRS-International Archives of the Photogrammetry, Remote Sensing and Spatial Information Sciences, vol. 422, pp. 25-32. 
Alessandri Luca, Baiocchi Valerio, Del Pizzo Silvio, Di Ciaccio Fabiana, Onori Matteo, Rolfo Mario Federico, Troisi Salvatore (2019). Three-dimensional survey of Guattari cave with traditional and mobile phone cameras. In Int. Arch. Photogramm. Remote Sens. Spatial Inf. Sci., vol. XLII-2/WII, pp. 37-4I.

Bolognesi Cecilia, Aiello Damiano (2019). From Digital Survey to a Virtual Tale:Virtual Reconstruction of the Convent of Santa Maria delle Grazie in Milan. In Bolognesi Cecilia, Santagati Cettina. Impact of Industry 4.0 on Architecture and Cultural Heritage. Hershey, PA: IGI Global. pp. 49-75.

Buchroithner Manfred, Milius Jeannette, Petters Christin (20I I). 3D surveying and visualization of the biggest ice cave on earth Proceedings of 25th International Cartographic Conference. Paris, France.

Cabrelles López Miriam, Lerma García José Luis (2013). Documentación 3D de abrigos rupestres a partir de láser escáner y de procesos fotogramétricos automatizados. In Virtual Archaeology Review, vol. 4(8), pp. 64-68.

De Vos Peter, De Rijk Melissa (2019). Virtual reconstruction of the birthplace of Rembrandt Van Rijn: from historical research over 3D modeling towards virtual presentation. In Int. Arch. Photogramm. Remote Sens. Spatial Inf. Sci., vol. XLII-2/WI5, pp. 397404.

Fabbri Stefano, Sauro Francesco, Santagata Tommaso, Rossi Guido, De Waele Jo (2017). High-resolution 3-D mapping using terrestrial laser scanning as a tool for geomorphological and speleogenetical studies in caves: An example from the Lessin mountains (North Italy). In Geomorphology, vol. 280, pp. I6-29.

Grasso Mario, Lentini Fabio (1982). Sedimentary and tectonic evolution of the eastern Hyblean plateau (southeastern Sicily) during Late Creataceous to Quaternary time. In Paleogeography Palaeoclimatology Palaeoecology, vol. 39, pp. 26 I-280.

Mohammed Oludare Idrees, Pradhan Biswajeet (2016). A decade of modern cave surveying with terrestrial laser scanning: A review of sensors, method and application development. In International Journal of Speleology, vol. 45(I), p. 8.

Nocerino Erica, Nawaf Mohamad M., Saccone Mauro, Ellefi Mohamed B., Pasquet Jérôme, Royer Jean-Philip, Drap Pierre (20 I 8) Multi-camera system calibration of a low-cost remotely operated vehicle for underwater cave exploration. In International Archives of the Photogrammetry, Remote Sensing \& Spatial Information Sciences, vol. 42( I), pp. 329-337.

Nocerino Erica, Menna Fabio, Farella Elisa Mariarosaria, Remondino Fabio (2019). 3D virtualization of an underground semisubmerged cave system. In Int. Arch. Photogramm. Remote Sens. Spatial Inf. Sci., vol. XLII-2/W I 5, pp. 857-864.

Paganini Paolo, Fingolo Margherita, Facco Lorenzo, Ceccato Alessio, Breganze Carlo, Cezza Marcello (20I I). Tra realtà virtuale e rilievi 3D ad alta risoluzione. In Veneto Geologi, pp. 2I-25.

Schilirò Francesco, Ruggieri Rosario, Cannata Andrea (2002). Necropoli di Pantalica: Carsismo e processi cinematici sul versante nord-orientale del Torrente Calcinara. In Speleologia Iblea, vol. I0, pp. 59-74.

Spena Maria Teresa, Allegra Filosico Manuela, Brogna Filadelfo, Dipasquale Costanza, Puma Antonio, Grasso Rosario, Agnell Paolo (20 I3). I chirotteri della Grotta dei Pipistrelli (SR): un unicum nella Sicilia sud-orientale. In Atti della Società dei Naturalist e Matematici di Modena, vol. I44, p. I7I.

Trizio Ilaria, Brusaporci Stefano, Luigini Alessandro, Ruggieri Andrea, Basso Alessandro, Maiezza Pamela, Tata Alessandra, and Giannangeli Alessandro (2019). Experiencing the inaccessible. a framework for virtual interpretation and visualization of remote, risky or restricted access heritage places. In Int. Arch. Photogramm. Remote Sens. Spatial Inf. Sci., vol. XLII-2NW I5, pP. | | $7|-| \mid 78$

\section{Authors}

Damiano Antonino Angelo Aiello, Università di Catania, damianoaiello@gmail.com Cettina Santagati, Università di Catania, cettina.santagati@dau.unict.it

To cite this chapter. Preservare la memoria: dal rilievo digitale alla realtà virtuale per la conservazione del patrimonio naturale a rischio/Preserving memory: from digital survey to virtual reality for the conservation of natural heritage at risk. In Arena A., Arena M., Brandolino R.G., Colistra D. Ginex G., Mediati D., Nucifora S., Raffa P. (a cura di). Connettere. Un disegno per annodare e tessere. Atti del $42^{\circ}$ Convegno Internazionale dei Docent delle Discipline della Rappresentazione/Connecting. Drawing for weaving relationships. Proceedings of the 42th International Conference of Representation Disciplines Teachers. Milano: FrancoAngeli, pp. I 5 I 0- 1527. 